УДК 811.111'42:004.774.Блог(73)

DOI: 10.18523/lcmp2522-9281.2020.6.5-16

Pavlo Zernetsky

https://orcid.org/0000-0003-4952-0747

Olena Kucherova

https://orcid.org/0000-0003-2350-2399

\title{
SEMANTIC STRUCTURES OF THE AMERICAN BLOG DISCOURSE
}

In this article the semantic structures of constructing American blog discourse are analyzed. Those structures are based upon semantic relations between propositions in the text of the blogs and aim to enhance coherence in this discourse. The results show that particular types of interpropositional relations are used on macro-semantic level for different subgenres of blogs (the semantic relations of equivalence, comparison, contrast, 'part-whole'/'whole-part', implication/causality, chronological order and spatial order relations). In particular, these interpropositional relations differ in the subgenres, such as political, business, socio-cultural, technology, and sports. In addition, the analysis brings out the different percentage of their usage.

Keywords: discourse, discourse analysis, blogs, proposition, speech event, interpropositional semantic relations.

\section{Introduction}

Interest in blog discourse has been on a sharp rise for a few decades. The proliferation of digital technologies and rapid growth of internet penetration made weblogs (blogs) an increasingly popular form of communication. Moreover, blogs are significant part of global communication (Zernetska, 2017). Being highly diversified in terms of content and user motivations for engaging with 
weblogs, blogosphere has become a mainstream genre of computer-mediated communication. Some bloggers become so successful that their readership is increasing dramatically. High-powered blogs are paid by advertisers to reach audiences online. The USA perhaps has the largest blogging community in the world and blogging there is still on the rise. Due to the fact that blogs are treated as a text type, or a genre, or a discourse, their aim and motivation need to be taken into account. So far, there has not been much research about the blog design.

\section{Theoretical background}

In recent years discourse analysts have focused on researching how language is used above and beyond the sentence by examining units larger than sentences and also by examining aspects of the world in which language is used. J. Lemke defined discourse analysis as "a set of techniques for making connections between texts and their meanings" (p. 79). Discourse analysis is a tool used to analyze the production of meaning in context (Gee, 2005). What linguists investigate is the actual utterances, the processes that influence the production of such utterances, and the meaning we give language. Through discourse, people organize thoughts into communicative actions and convey communicative intentions. Linguists focus on how language is used in context. Writers, readers, and situations are also the realm of analysis.

Traditionally written discourse is opposed to spoken discourse (Sindoni, 2013). Discourse can be created by speaking or writing and these two processes rely upon language in strikingly different way. As a result, their products achieve coherence through very different means. Blogs stand somewhere between speech and writing. Thus, blog discourse is somewhat the combination of properties of written and spoken discourse. Cohesive ties between propositions show recipient design - the process whereby a speaker takes the listener into account when presenting information.

In terms of communication type, blogs resemble us public speaking. Public speaking is viewed as expanded conversation with three important characteristics of good conversation: direct and spontaneous, colorful and compelling, and tuned to listeners (Osborn, \& Osborn, 2000, p. 11). What does this mean? First, although the blog post is planned and written beforehand, it addresses its audience just like an oral speech. The author of the blog is addressing the readers in an engaging way, almost as if they are talking to them. Second, just 
like effective speeches, successful blogs are colorful and compelling, conveying colorful conversational qualities that audience enjoy so much. Last but not least, blogs monitor their readers' reaction, which is, however, postponed in time. The author of a blog a kind of predicts this reaction providing additional facts, examples, and expert opinions. In this way the author answers all possible questions of the audience.

Moreover, similar to public speaking, the roles of writer and reader are clearly defined. Good blogs like good speeches are products of thorough research, careful planning, and appropriate design. The reader will 'trust' the author who seems to be competent in their subject. The author plans speech events. The right blog design contributes to credibility and charisma of its author.

We focus our attention on utterances as minimal units of discourse. Utterances are communicative units and their meaning is shown in propositions as discourse units. Thus, to study the discourse semantics, we analyze semantic features of propositions. In linguistic sense the term 'proposition' describes the semantic structure that manifests the cognitive meaning of the utterance. And semantic relations between propositions form some certain types of discourse design.

Macro- and micro-semantic relations between propositions constitute the structural basis for the dynamic aspect of discourse development, which is usually, analyzed with the help of corresponding strategies and tactics (Kuranova, 2018). We differentiate the status of semantic relations between propositions into macro relations and micro relations according to the scope of their use. The text of the blog is understood as a speech event, which is the basic analytical unit for the analysis of verbal interaction and can consist of single utterances or stretches of utterances (Gumperz, 1986, p. 16-17). We analyze the relations which exist between different propositions within the whole blog as a speech event and are called macro semantic relations.

We aim to explore the structure of American blog discourse that involves the linguistic processes of arranging sentences to convey meaning and cognitive processes that underlie the organization of thoughts into verbal forms. Our critical analysis of American blog discourse goes beyond the usual description of grammatical and rhetorical structures and is based on an explicit theory of "context" (van Dijk, 2009) that is able to relate such discourse to the social situation understood by the participants. 
It is important to remember that a key feature of a discourse is coherence there are structured relationships among its parts, some patterned relationships among sentences and among ideas. The role of lexical patterns in written texts had been the object of detailed attention, especially within the study of lexical cohesion (Halliday, \& Hasan, 1976; Hasan, 1984). Multiple ties between words in written texts had been meticulously recorded by M. Hoey (1991). For some years, a variety of studies have been conducted to investigate discourse coherence (Kucherova, 2005; Kuranova, 2012; Riabokon, 2004). The concept of coherence describes not only something that exists in structures of discourse, but also something that exists in people.

In American blog discourse different kinds of processes and different configurations of language work together to produce coherence. Depending on the blog topic/subgenre the writer uses different designs to construct their discourse for their projected recipient. A good way to see this is to compare different topics/subgenres with one another. This can be called the comparison between registers, ways of using language that reflect different facets of its context such as participants, goals, and settings.

Subgenres are the recurrent uses of more or less conventionalized forms through which authors of blogs communicate meaning, get things done using language. Blogs subgenres can thus be seen as a kind of tacit contact between writers and readers, which influence the behaviour of text producers and the expectations of receivers.

Special interest presents the semantic peculiarities of different subgenres of blogs. We single out traditional subgenres of blogs according to the spheres of social-economic life of the society: political, socio-cultural, business, technology, and spots blogs. The most informative from the point of view of the meaning structure of those blogs subgenres can be the analysis of the semantic relations between their propositions. We consider it most appropriate to apply the set of relations between propositions (interpropositional relations) reviewed by P. Zernetsky (1992, pp. 59-97) based on the American neo-rhetorical tradition, which often view them as thought relations (Adams, \& Dwyer 1982; Arnaudet, \& Barrett, 1984; McQuade, \& Atwan, 1988; Raskin, \& Weiser, 1987). Those semantic interpropositional relations were consequently developed in American and Canadian works (Conrad, 2001; Jordan, 2006; Swales, \& Feak, 2017). Among the most frequently mentioned types of semantic interpropositional relations are the following: exemplification, definition, contrast, 
comparison, enumeration, chronological order, process, causality, spatial order, identity, and equivalence. In terms of the specific number and type of interpropositional relations, the authors of neo-rhetorical textbooks differ mostly in singling out such relations as exemplification, illustration, definition, general-to-specific (induction), and specific-to-general (deduction), which can be analyzed as subtypes of one general type 'part-whole'/'whole-part' relations. In this research we apply such types of semantic interpropositional relations, as identity, equivalence, similarity, contrast, 'part-whole'/'whole-part' relations, spatial order relations, chronological order relations, and semantic relations of implication/causality to analyze the relations between propositions that are situated both closely and distantly in blogs. Those types of relations are divided into two major groups: equivalent and non-equivalent. To the equivalent ones belong the relations of identity and equivalence proper. To the non-equivalent relations we refer the relations of similarity, the relations of contrast, 'part-whole'/'whole-part' relations, spatial order relations, chronological order relations, and semantic relations of implication/causality.

The aim of this paper is to analyze the distinctive features of American blog discourse from the perspective of semantic communicative functional approach. In accordance with this approach, the semantic structure of American blog discourse is analyzed. In other words, how information is linked through cohesive ties. We aim to analyze the design of the most popular American blogs in order to see how rhetoric impacts on writing skills. We are the first to take the functional approach to the analysis of linguistic performance when authors construct blog discourse.

By defining the type of semantic relations between propositions, we conduct propositional analysis. In this way we describe how genre characteristics of blog discourse are presented in language. Comparing texts of the same subgenre in different blogs, we pinpoint the elements that repeat. As a result, discourse design patterns are suggested.

\section{Methods}

The method of interpropositional semantic analysis was applied to describe the semantic structure of American blogs. The statistical modelling method was also used to describe the usage of particular type of semantic relations between propositions in a definite blog subgenre. Thus, we have outlined some 
major design formats that are used in the most successful blogs and have described the main linguistic patterns of such blogs.

For this we have analyzed the most successful blogs in the USA. The corpus includes articles published during the year 2019. The corpus of media websites includes the most "powerful" and the most "valuable" blogs in the world according to the British newspaper 'The Guardian' and an American magazine 'The Atlantic' respectively: 'The Huffington Post' (huffingtonpost. com), 'Mashable' (mashable.com), 'Techcrunch' (techcrunch.com), and 'Business Insider' (businessinsider.com). The salient feature in this genre is the mixture of informative and persuasive rhetorical modes.

\section{Results and discussion}

The research clearly demonstrates that distinctive differences in genres lead writers to employ different rhetorical choices. In our analysis we focus on the patterns in which sentences (and other units such as acts and turns) appear in the texts that are constructed when authors write their blogs. Believing that the form of language is governed by abstract linguistic rules that are part of writers' competence, we focus on principles that guide performance, the use of language. These principles are based on certain linguistic patterns that can be explained through definite relationships between propositions. The combination of such interpropositional relations constructs the structure of American blog discourse.

The interpropositional relations can be classified into two types: equivalent and non-equivalent relations. To the equivalent ones belong the relations of equivalence proper and the relations of identity. To the non-equivalent relations we refer the relations of comparison, the relations of contrast, "partwhole'/'whole-part' relations, spatial order relations, chronological order relations, and semantic relations of implication/causality.

(1) Semantic relations of comparison realize speech intention of the author to establish resemblance between the objects of description. Let us consider an example. In the socio-cultural article by a freelance journalist Joanna York 'Meghan Markle's Suffering Has Forced The British Public To Take A Look At Themselves' Meghan Markle is compared to Princess Diana (Huffpost 21/10/2019).

(2) Semantic relations of contrast presuppose the existence of two or more objects that oppose one another. The author can construct blog discourse using 
semantic relations of contrast between propositions. For instance, in the socio-cultural article 'Disabled People Call Out Things Non-Disabled People Don't Realize Are Offensive' the author discusses the problem of ableism and in a certain way contrasts disabled people to non-disabled people (Huffpost 31/12/2019).

By and large, interpropositional semantic relations of contrast and interpropositional semantic relations of comparison on the whole intervene in blog discourse, in particular in its socio-cultural subgenre. For example, the article 'YouTube college rejection videos are more hopeful than you'd expect' compares two college-bound vloggers, who are able to speak about their misfortune in an upbeat way. The author of the article does this in a pretty explicit way, using the lexical connector similarly. In the same article college rejection videos and breakup videos are contrasted with acceptance videos:

College rejection videos have been around for a few years (acceptance videos have, too) but they're a far more interesting watch than their counterparts. In an acceptance video, the plot hinges on which college the YouTuber will attend ... But a rejection video, like its sister genre, the breakup video, is a look into the vlogger's life that feels much more voyeuristic. Why? It's about rejection, something we all recognize as bad. Something connected to shame. Something we would probably not want to broadcast to the world. Vloggers do it ... (Mashable 04/04/2019).

(3) 'Part-whole'/'whole-part' relations are based on the fact that the surrounding world consists of objects, processes, and phenomena of different volumes and statuses. Two different ways of description are usually singled out: deductive and inductive. From semantic point of view the relational basis of deductive and inductive ways of description in discourse are constituted correspondingly by the relations 'whole-part' and 'part-whole'. When in a business blog the semantic relations 'whole-part' is used, the author first introduces the idea that the company is currently discussing specific policies that would police deepfakes, which is 'whole'. Then mentions one particular example of a video to illustrate deepfake: a manipulated video of Nancy Pelosi (Mashable 27/06/2019).

(4) If the contents of discourse or its part is organized with the help of description of the place of phenomena (processes, facts) in space, the semantic relations between corresponding propositions are called spatial order 
relations. For sports blogs it is vitally important where the action takes place. As a result, the author uses spatial pattern of organization. First of all, we need to know where the sportsperson is from, here the Netherlands-based Hassan, Sifan Hassan of the Netherland, Hassan, who moved to the Netherlands after leaving Ethiopia. Then the author states where the action takes place: Monaco, in Doha (at the world championships) (Huffpost $17 / 12 / 2019)$.

(5) Propositions can be connected in discourse by the reference to the notion of time. Such class of semantic relations is called chronological order. The author tells the story in a blog devoted to technology in a chronological order using time expressions, such as late afternoon on May 12, 2017, hours earlier, hours after the disruption began, hours after it began on May 12, by 6:30 p.m., by 7 a.m., in August 2017. The author also uses references to earlier events: since the likes of Blaster and Mydoom in the early 2000s (TechCrunch 08/07/2019).

Another example of temporal semantic relations comes from the political article: The state was taking a big step to keep its elections from being hacked in 2020. Last April, its top election official told countries they had to update their system. ... That's significant because Windows 7 reached its "end of life" on Jan. 14, meaning Microsoft stops providing technical support and producing "patches" to fix software vulnerabilities, which hackers can exploit. In a statement to the AP, Microsoft said Friday it would offer continued Windows 7 security updates for a fee through 2023. ... (Huffpost 14/07/2019).

(6) Different groups of implication/causality relations include relations of the types 'cause-effect' or 'means-result'. In the article of the subgenre of technology the author first describes the situation: Huawei was placed on the Commerce Department's Entity List, the Chinese telecom equipment and smartphone giant will be able to do business with American suppliers again - but only if they get a license from the U.S. government. After this the author describes the consequences: the promise created confusion about how it would be carried out, Huawei...is a major bargaining chip in the ongoing trade war between the U.S. and China. The author also states the consequences of the opposite action, such as being blacklisted. Such consequences are the following: The blacklist has had a major impact on Huawei, with important suppliers like Qualcomm, Intel and Google severing ties, blacklist 
would cost the company about $\$ 30$ billion in revenue, U.S. companies have lost an important customer (TechCrunch 10/07/2019).

Let us consider another example of implicative relations of the type 'problem-solution'. In the political article 'After The Essex Lorry Deaths, What Will It Take To Realise Harder Borders Cause These Tragedies?' the author poses the problem of migrant smuggling or human trafficking at the beginning of the blog and suggests some possible solutions in the rest of the blog (Huffpost 16/10/2019).

The relations of (7) equivalence are based on the preservation of information in the next proposition compared to the previous proposition. Equivalent relations can be extensional, intensional, and extensio-intensional. Extensional equivalence takes place in the case of substitution with the help of pronouns or substitutional words (such as one or $d o$ ) of a part or the whole previous proposition in the next proposition. Intensional equivalence includes the cases of variation of the predicate of propositional unit in the next proposition. The same idea or event, important from the author's point of view, can be mentioned several times in the text using different lexical resources, for example: plunged; slumped; slowdown; dropped (Business Insider 03/07/2019). Extensio-intensional equivalence presupposes the use of discourse markers of the type 'I mean', 'that is', 'in other words', 'in a sense' and other expressions.

The semantic relationship of equivalence can also be illustrated in the following example. In the socio-cultural article 'Who Are We Kidding, Racism Is An Open Secret At Universities' the author repeats the main language elements:

racial harassment is "a common occurrence" for students across the UK; Students and staff of British universities were both found to have been subject to racist name-calling, insults, "jokes", and even physical attacks.; being targets of racial abuse; Racism is something of an open secret in university life.; black women are perceived in modern day society - angry, hypersexual, loud; in the face of overt and covert racism; Racist material and displays were found to be a regular part of promoting students society events.; Many students have experienced casual racism not only from their peers, but from academic staff.; people in a position of authority are complicit in and perpetuate racism (Huffpost, 23/10/2019). 
The relations of (8) identity prosupose a) repetition of all the language elements of the previous proposition in the next proposition; b) omission of some language elements of the previous proposition in the next proposition; c) addition of some language elements in the next proposition; d) both addition and omission of some language of the previous proposition in the next proposition. This type of interpropositional relations is not characteristic of the discourse analyzed in this study.

\section{Conclusions}

The results of the analysis of American blog discourse show that distinctive differences in subgenres lead writers to employ different rhetorical choices. Interpropositional structure of those subgenres really differs as to the proportion of this or that type of semantic relations between propositions, which are predominantly non-equivalent. Our calculations show that the most prominent type of interpropositional relations in blogs dedicated to politics is chronological order (32\%) and spatial order relations $(28 \%)$. They are followed in number by the relations of implication (2\%). Business blogs are remarkable by the active use of interpropositional relations of implication (39\%), 'part-whole'/'whole-part' relations (28\%), and macro-semantic relations of equivalence $(21 \%)$. The macro-semantic structure of socio-cultural blogs is predominantly developed with the help of the interpropositional relations of equivalence $(31 \%)$, comparison $(16 \%)$, contrast $(14 \%)$, chronological and spatial order relations $(11 \%)$. The interpropositional relations of chronological order and spatial order are usually closely connected with each other especially in socio-cultural blogs. For the genre of technology the authors tend to use chronological order relations $(47 \%)$, relations of implication (18\%), and spatial order relations (15\%). Sports blogs abound in spatial order relations $(32 \%)$. Chronological order relations $(29 \%)$ and relations of contrast $(16 \%)$ are also numerous. The new data on correlation of different types of semantic relations between propositions provide a significant insight into semantic structure of discourse of blogs in our case American ones.

\section{References}

Adams, J.-A., \& Dwyer, M. A. (1982). English for academic uses: A writing workbook. Englewood Cliffs, New York. 
Arnaudet, M., \& Barrett, M. (1984). Approaches to academic reading and writing. Englewood Cliffs: Prentice-Hall.

Conrad, R. (2001). Process \& practice. Toronto: McGraw-Hill Ryerson.

Dijk, van T. A. (2009). Society and Discourse How Social Contexts Influence Text and Talk. Cambridge University Press.

Gee, J. P. (2005). An Introduction to Discourse Analysis: Theory and Method(1999). Second Edition. London: Routledge.

Gumperz, J. (1986). Introduction. In J. Gumperz, \& D. Hymes, Directions in sociolinguistics. Oxford: Basil Blackwell.

Halliday, M. A. K., \& Hasan, R. (1976). Cohesion in English. London: Longman.

Hasan, R. (1984). Coherence and cohesive harmony. In J. Flood (Ed.), Understanding Reading Comprehension (pp. 181-219). Newark, Delaware: International Reading Association.

Hoey, M. P. (1991). Patterns of Lexis in Text. Oxford: Oxford University Press.

Jordan, R. (2006). Academic writing course. Harlow: Longman.

Kucherova, O. O. (2005). Semantychni stratehii i taktyky pobudovy planu zmistu brytanskoho hazetnoho novynnoho dyskursu [Semantic strategies and tactics of content construction of British newspaper news discourse]. Mandrivets, 1, 62-71 [in Ukrainian].

Kuranova, S. I. (2018). Stratehii, taktyky ta pryiomy movlennievoi diialnosti iak component modeliuvannia dyskurs-portreta movnoi osobystosti [Semantic strategies and tactics of content construction of British newspaper news discourse]. Mova: klasychne-moderne-postmoderne, 4 , 33-47 [in Ukrainian].

Kuranova, S. I. (2012). Zistavnyi aspect mizhpropozytyvnykh vidnoshen v amerykanskomu ta ukrainskomu publichnykh dyskursakh [Comparative aspect of the interpropositional semantic relations in the American and Ukrainian public discourses]. Naukovi zapysky NaUKMA. Filolohichni nauky (Movoznavstvo), 137, 153-156 [in Ukrainian].

Lemke, Jay L. (2012). Multimedia and discourse analysis. In J. P. Gee, \& M. Handford, (Eds.), The Routledge Handbook of Discourse Analysis (pp. 79-89). London: Routledge.

McQuade, D., \& Atwan, R. (1988). Thinking in writing. New York.

Osborn, M., \& Osborn, S. (2000). Public speaking. Boston: Houghton Mifflin.

Raskin V., \& Weiser, I. (1987). Language and writing: Applications of linguistics to rhetoric and composition. New Jersey: Norwood.

Riabokon, H. L. (2004). Semantychni mizhpropozytsiini vidnoshennia rivnoznachnosti ta implikatsii u brytanskomu parlamentskomu dyskursi [Semantic relations between propositions of equality and implication in British parliamentary discourse]. Mandrivets, 5, 22-29 [in Ukrainian].

Sindoni, M. G. (2013). Spoken and written discourse in online interactions. London: Routledge.

Swales, J., \& Feak, C. (2017). Academic writing for graduate students. Ann Arbor: The University of Michigan Press.

Zernetska, O. V. (2017). Hlobalna komunikatsiya: monohrafiya [Global communication]. Kyiv: Naukova dumka [in Ukrainian].

Zernetskyi, P. V. (1992). Riechievoie obshchieniye na anhliyskom iazykie (Kommunikativno-funktsionalnyi analiz diskursa) [Speech communication in English (Communicative-functional discourse analysis)]. Kiev: Lybid [un Russian]. 


\section{Павло Зернецький, Олена Кучерова}

\section{СЕМАНТИЧНІ СТРУКТУРИ В ДИСКУРСІ АМЕРИКАНСЬКИХ БЛОГІВ}

Постановка проблеми. 3 лінгвістичного погляду цікавим є дослідження побудови дискурсу блогів як новітніх 3МІ. На семантичному рівні важливим $є$ поняття зв'язності дискурсу, тобто як значення пропозицій пов'язані між собою у тексті блогу. Семантичні відмінності між пропозиціями допомагають будувати дискурс залежно від інтенцій автора. Ми проводимо макрорівневий аналіз дискурсу і вивчаємо відношення між пропозиціями, що розташовані і контактно, і віддалено одна від одної в тексті блогу. Семантичні відношення між пропозиціями лежать в основі семантичних структур побудови дискурсу блогів.

Мета статті. Метою статті є визначення певних структур побудови дискурсу американських блогів із погляду семантичного комунікативно-функціонального підходу, а також з'ясування, як саме жанрові характеристики дискурсу блогів відображено у мові.

Методи дослідження. Методи дослідження передбачають відбір та аналіз інтернет-статей різних піджанрів у провідних американських блогах за 2019 рік. Було застосовано методи міжпропозитивного семантичного аналізу і метод статистичного моделювання для опису семантичних структур і піджанрових особливостей використання міжрівневих семантичних відношень.

Основні результати дослідження. Результати дослідження свідчать, що для продукування різних піджанрів блогів (у сферах політичній, соціально-культурній, економічній, технологічній і спортивній) характерним $\epsilon$ використання автором дискурсу різних семантичних структур. Виявлено основні семантичні структури для окремих піджанрів та описано лексико-семантичні засоби розгортання змісту дискурсу.

Висновки і перспективи. Визначено типові риси дискурсу американських блогів. Семантичні структури побудови дискурсу американських блогів визначено як комбінацію певних міжрівневих переважно нееквівалентних семантичних відношень.

Ключові слова: дискурс, дискурс-аналіз, блоги, пропозиція, мовленнєва подія, міжпропозитивні семантичні відношення.

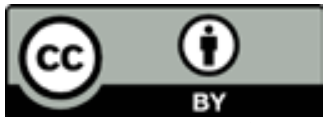

Матеріал надійшов 23.04.2020

Creative Commons Attribution 4.0 International License (CC BY 4.0) 